\title{
Students' Task Understanding during Engineering Problem Solving in an Introductory Thermodynamics Course
}

\author{
Oenardi Lawanto ${ }^{1}$, Angela Minichiello ${ }^{1}$, Jacek Uziak $^{2} \&$ Andreas Febrian ${ }^{1}$ \\ ${ }^{1}$ Engineering Education Department, College Of Engineering, Utah State University, Utah, USA \\ ${ }^{2}$ Department of Mechanical Engineering, Faculty of Engineering and Technology, University of Botswana, \\ Gaborone, Botswana \\ Correspondence: Oenardi Lawanto, Engineering Education Department, College of Engineering, Utah State \\ University, Utah, USA. Tel: 1-435-797-8699. E-mail: olawanto@usu.edu
}

Received: February 9, 2018

Accepted: March 19, 2018

Online Published: June 28, 2018

doi:10.5539/ies.v11n7p43

URL: https://doi.org/10.5539/ies.v11n7p43

\begin{abstract}
Understanding problems or tasks is a critical step in any problem-solving activity and the heart of self-regulated learning. When encountering a problem, students draw upon information available in the environment, along with knowledge, concepts, and perceptions derived from prior learning experiences, to interpret the demands of the task. Interpretation of tasks is, therefore, a key determinant of the goals set while learning, strategies selected to achieve those goals, and the criteria used to self-assess and evaluate outcomes. The purpose of this study is to better understand engineering students' self-regulation in task interpretation processes while engaged in problem solving in an introductory engineering thermodynamics course. Two research questions guided the study: (1) What are the gaps, if any, between the instructor's and students' interpretation (explicit and implicit task features) of a problem-solving task?; and (2) How do students' task interpretation (explicit and implicit) change after engaging in self-evaluation of their problem-solving processes? One hundred twelve (112) second year engineering undergraduates voluntarily participated in the study. Analysis of the data collected revealed a significant difference between the instructor's and students' task interpretation of the assigned problems. Furthermore, the analysis showed that students' had a higher ability to identify the explicit parts of problem tasks than implicit ones. Students were able to grasp 63 to 77 percent and 39 to 49 percent, respectively, of the explicit and implicit information that was presented to them while engaged in problem-solving activities.
\end{abstract}

Keywords: task understanding, task interpretation, self-regulated learning, problem-solving, engineering education

\section{Introduction}

Understanding the problem is a critical step in any problem-solving activity. Student's understanding of an assigned task determines the strategies they select for completing the task (Butler, 1998). Task interpretation (TI), which refers to how students perceive an academic task (Butler, 1998), has emerged in the literature as an important component of self-regulated learning (SRL) and, consequently, academic success (Andrade \& Valtcheva, 2009; Boekaerts, 1997; Coutinho, 2007; Downing, Kwong, Chan, Lam, \& Downing, 2009; Ferla, Valcke, \& Schuyten, 2009; National Research Council, 2000; Otero, Campanario, \& Hopkins, 1992). TI is the first step in the self-regulated learning (SRL) process because students' interpretation of the task assigned is a key determinant of the goals they set while learning, the strategies they select to accomplish the goals, and the criteria they use to self-evaluate outcomes for academic success (Butler \& Cartier, 2005).

Engineering problem solving requires students to apply scientific and mathematical principles to develop quantitative estimates of physical phenomena (Engineering Accreditation Commission, 2003). Similarly, learning to solve problems effectively and confidently often requires students to engage in problem-solving practice and critical self-reflection over a sustained period of time. The focus of this study was students' task interpretation during problem-solving activities in an undergraduate engineering thermodynamics course. This course purposefully emphasizes the combination of problem-solving activities and individual self-evaluation of problem solutions in order to promote conceptual understanding through application and reinforcement. Understanding a problem is the first critical step leading to strategies to achieve the solution. Problem definition is always the first step in any model for problem-solving process (Jonassen, 2004; Kim \& Kim, 2015; Koichu \& Leron, 2015; Polya, 
1957). However, successful problem definition requires a strategy to understand the problem.

\section{Brief Relevant Literature Review}

A self-regulated learning (SRL) in this study is defined as a complex repository of knowledge and skills for planning, implementing, monitoring, evaluating, and continually improving the learning process (Butler \& Cartier, 2005; Butler \& Winne, 1995). Research on SRL shows that enhancement of these abilities strengthens learning skills (Wolters, 1998) and improves academic success (Andrade \& Valtcheva, 2009; Boekaerts, 1997; Downing et al., 2009; Ferla et al., 2009; National Research Council, 2000). Coutinho (2007), along with Otero and Campanario (Otero et al., 1992), found that students with good SRL skills are more likely to achieve academic success and a high grade point average (GPA). In addition, they are more knowledgeable and responsible for their cognition (Pintrich, 2002) and accomplish cognitive actions more successfully (Paris, 1986). Students with poor SRL capability may benefit from instructional processes specifically designed to improve their metacognitive abilities and learning (Coutinho, 2008; Marchis, 2011; Samuelsson, 2008). According to Zimmerman, Heart, and Mellins (1989), self-regulated learners are "metacognitively, motivationally, and behaviorally active participants in their own learning process" (p. 329); therefore, self-regulated learners are skilled in goal-setting, self-monitoring, self-instruction, and self-reinforcement (Schraw, Crippen, \& Hartley, 2006). Previous studies suggest that self-evaluation ability is essential in science (Georghiades, 2000; Rickey \& Stacy, 2000), technology (Phelps, Ellis, \& Hase, 2002; Phelps, Graham, \& Thornton, 2006), engineering (Case, Gunstone, \& Lewis, 2001; Lawanto, Butler, Cartier, Santoso, Lawanto, et al., 2013; Lawanto, Butler, Cartier, Santoso, \& Goodridge, 2013), and mathematics (Carr \& Biddlecomb, 1998; De Corte, Mason, Depaepe, \& Verschaffel, 2011).

As a cognitive control process, SRL is tied to metacognition. Emphasizing the use of the terms 'metacognition' and 'self-regulation', Dinsmore, Alexander, and Loughin (2008) stated that, "We see a clear cognitive orientation of metacognition, while self-regulation is as much concerned with human action than the thinking that engendered it" (p. 405). Furthermore, researchers have maintained that the important issue in self-regulation and metacognition is to understand "the correspondence between metacognition and action. How do thoughts and feelings of learners guide their thinking, effort, and behavior?" (p. 21) (Paris \& Winograd, 1990).

The dynamic and iterative interplay between metacognitive and cognitive activities is described by Butler and Cartier (Brydges \& Butler, 2012; Butler \& Cartier, 2004, 2005; Butler, Schnellert, \& MacNeil, 2015; Butler \& Winne, 1995; Cartier \& Butler, 2004) in their SRL model, which characterizes SRL as a complex, dynamic, and situated learning process (see Figure 1). This model consists of a learner, a learning environment, and learner's continuous engagement with the confined environment in various contexts (e.g., instructional approach, discipline, or faculty). The learner refers to one's experience, strengths, challenges, metacognition skills, knowledge, and beliefs. The learning environment refers to the given task or activity, available resources, and feedback. The learning engagement refers to continuous activities of understanding a task, developing a plan according to task understanding, acting on the plan developed, monitoring progress and results, and adjusting approach if necessary. Further, the model also proposes that learning engagement is affected by learner's emotions and motivations.

Hadwin, Oshige, Miller, and Wild (2009) offers a complementary model that further describes the explicit, implicit, and socio-contextual aspects of task interpretation. In this study, explicit features of assigned tasks include information that is overtly presented in problem descriptions, such as the task goal or requirements. Implicit features of a task include any information beyond the problem description, such as relevant concepts or procedures. Socio-contextual aspect refers to learner's awareness about the contexts surrounding the task, which is considered as part of the layers of contexts in the Butler and Cartier's model.

Mairing (2016) reported that learners' conceptual knowledge and structure influence their task interpretation, such that a naïve problem-solver tends to have a limited understanding of a problem; these results are consistent with the models described in this study (Brydges \& Butler, 2012; Butler \& Cartier, 2004, 2005; Butler et al., 2015; Butler \& Winne, 1995; Cartier \& Butler, 2004; Hadwin et al., 2009). Lubis and Nasution (2017) argue that each learner's initial task interpretation is unique because they have different levels of conceptual understanding. Fortunately, students' understanding has been shown to evolve as they work through the problem (Rivera-Reyes, 2015; Rivera-Reyes, Lawanto, \& Pate, 2017) and interact with their peers (Rivera-Reyes, Lawanto, \& Pate, 2016). As their task interpretation mature, students also adjust their approach to solving the problem (Abdillah, Nusantara, Subanj, Susanto, \& Abadyo, 2016; Kahneman, 2003). Moore, Miller, Lesh, Stohlmann, and Kim (2013) argue that due to the nature of engineering problems, there are some constraints that cannot be easily identified from the beginning, which then require the engineers to work iteratively through the problems. 


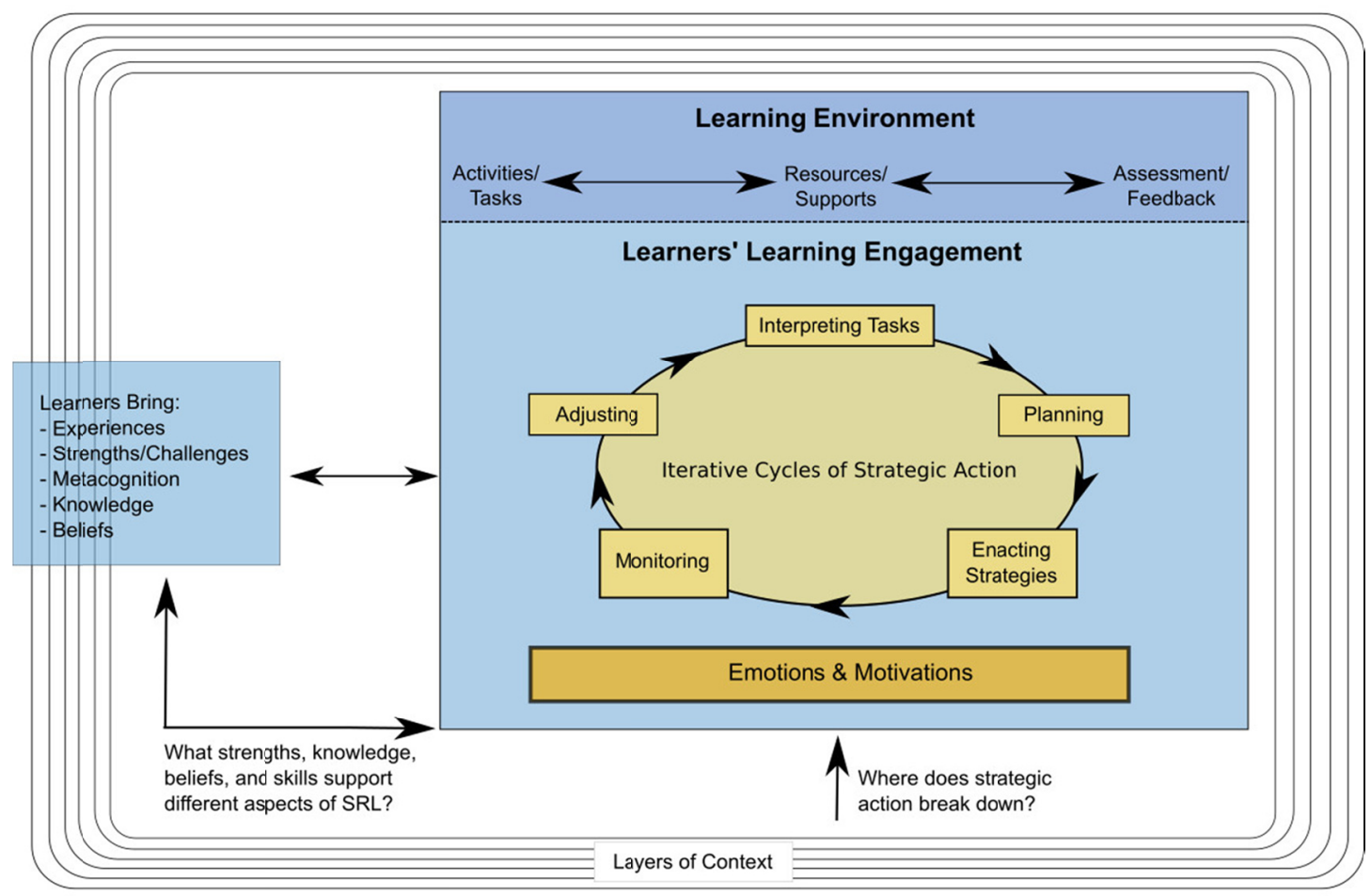

Figure 1. Self-regulated learning situated in problem-solving context; adopted from Butler, Schnellert, and MacNeil (2015) based on the work of Butler and Cartier (2004) and Cartier and Butler (2004)

\section{The Study}

\subsection{Purpose and Research Questions}

The purpose of this study is to develop deeper understanding of engineering students' self-regulation in task interpretation processes while engaged in problem solving tasks in an introductory engineering thermodynamics course. This study also seeks understanding about how student self-evaluation during problem solving activities influences students' understanding of the problem (or task) they are working on.

Findings from this research are expected to lead to improvements in the instruction of teaching engineering and thermodynamics in particular. It is also the intent of this study to assess how student self-evaluation of the problem solution may improve their task interpretation skills while solving problems with various level of complexity. The ultimate goal of future instructional interventions is not only to improve the effectiveness of teaching engineering problem solving, but also to develop more positive attitudes toward these critical skills among engineering students.

This research focuses on two of the three layers of information suggested in Hadwin, Oshige, Miller, \& Wild (2009)'s model of task understanding that inform constructions of task understanding: explicit and implicit information about tasks.

Two research questions were developed to guide this research:

1) What are the gaps, if any, between the instructor's and students' interpretation (explicit and implicit task features) of a problem-solving task?

2) How do students' task interpretation (explicit and implicit) change after engaging in self-evaluation of their problem-solving processes?

\subsection{Context of the Study}

Engineering Thermodynamics, a foundational sophomore-level course that is required for aerospace, mechanical, and all related engineering majors, was selected as the course context of this study. The goal of this course is to examine the relationships between different energy forms (i.e., heat and work) and to develop students' ability to analyze processes and cycles that rely on energy transformation, such as power generation and refrigeration. 
Within the course, weekly problem sets were assigned in the manner proposed by Kearsley \& Klein (2016). Problem solving assignments were posted electronically to the course learning management system (LMS) and students were given one week to solve and turn in their handwritten solutions by scanning and uploading them to the LMS. Immediately after this first submission, the instructor posted detailed problem solutions on the LMS. Students were required to review and make corrections to their work based on these solutions. The instructor required corrections to be written in different color in order to differentiate between students' initial and corrected solutions. Students' were required to submit their corrected work for instructor assessment within two to three days after the initial submission. An example of one student's corrected problem solution is shown in Figure 2.

One hundred and twelve (112) students (10 female and 102 male) participated in the study. The participation level of female students in the study (10 out of 112 or $8.9 \%$ ) closely represents the gender demographics of the course (12 out 127 or $9.4 \%$ of the students in the course were female). Participation was voluntary; participants were reminded that they could withdraw at any time. The participants were informed of the purpose of the study during class by researchers who were not the course instructor. The researchers encouraged students to participate in the research, offering compensation with extra credit for their participation. Students who participated in the research received a maximum of eight extra credit points. Students who chose not to participate were given the opportunity to earn equivalent extra credit points by working on other assignments requiring a similar level of effort. Students who participated were required to sign a consent form as part of the processes approved by the Institutional Review Board (IRB).

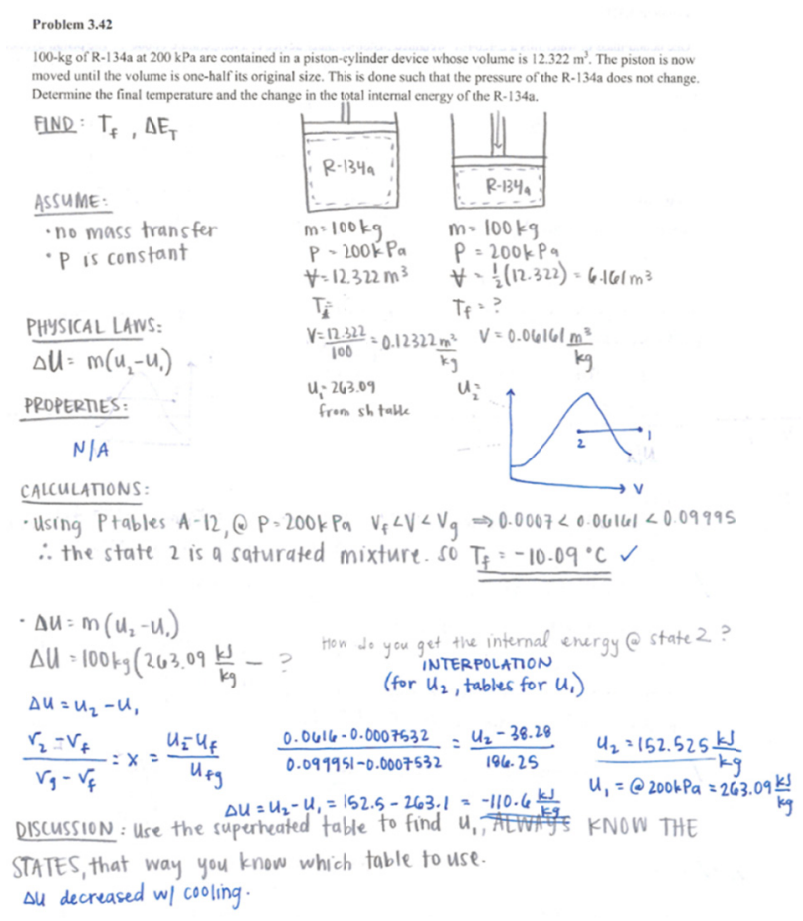

Figure 2. Student's self-evaluation of the problem solution

\subsection{Data Collection and Analysis}

Data were collected from participating engineering students who were enrolled in Engineering Thermodynamics course in spring 2017 semester. Qualitative data, in the form of open-ended textual responses to task analyzer questionnaire (i.e., TAQ) administered online, were gathered for three assigned thermodynamic problems both before and after students self-evaluated their problem-solving assignments using the detailed solution key provided by the instructor. Each problem was related to one unique course topic including (1) Closed System Energy Analysis (First Law), (2) Open System Entropy Balance (Second Law), and (3) Ideal Cycle Analysis. Specifically, the three problems were assigned during the 7th, 13th, 15th weeks of the course, respectively. Difficulty of the assigned problems for this research closely represented the same level of difficulty as problems discussed in class, assigned for preparation out of class, and assessed during exams. Due to the cumulative nature of content within the course, the first problem could be considered "least difficult" and the last problem "most 
difficult" if compared against each other.

Qualitative data were collected through Task Analyzer Questionnaire (TAQ) to assess the participants' task interpretation. Unique TAQ was developed for each specific assignment (i.e., the three problem solving assignments described earlier). The TAQ has been face-validated, construct-validated, and pilot-tested, and then revised accordingly prior this study. Each TAQ consisted of eight open-ended questions and included items related to both explicit and implicit aspects of task interpretation as described by Hadwin et al. (2009). Examples of an explicit and implicit task interpretation questions were "What were your goals in solving this problem? (In other words, what were you asked to do?)" and "List the major concepts and/or principles discussed in class that you used in solving this problem", respectively.

Two raters assessed student's task interpretation of each problem: the course instructor and another engineering faculty member who was also a content expert. In order to generate the TAQ responses used to rate student responses, the instructor provided initial TAQ responses. Next, the content expert evaluated these responses. After discussions between the instructor and content expert, revisions were made to the instructor's responses. The revised responses were used to score students' answer.

Students' TAQ scores ranged between from 0 to 2 . A TI score of 0 was assigned to a blank or incorrect answer; a score of 2 was given to a correct answer (i.e., when students were able to describe at least half of the possible correct responses); and a score of 1 indicated an incomplete answer. The score applied to an incomplete answer was mutually agreed on by the raters after comparing the incomplete answer to the problem solution. Together, the two raters achieved an inter-rater reliability score of 97 percent agreement.

To analyze the score, a comparison of the means of students' TAQ responses before and after self-evaluation of the problem solution was conducted. Next, two-tailed paired-sample t-tests were conducted. A cutoff value of .05 for Type 1 error was used to determine whether the results of the TAQ before and after are significant.

\section{Results}

4.1 Addressing Research Question 1: What Are the Gaps, If Any, between the Instructor's and Students' Interpretation (Explicit and Implicit Task Features) of a Problem-Solving Task?

To investigate whether there were any gaps between the instructor's and students' interpretation of a task, three sets of paired-t-tests were conducted (see Table 1). The first test set was conducted to evaluate the mean differences between overall (i.e., combined explicit and implicit) task interpretation scores of instructor and students (i.e., overall students' TI before and after engaging in self-evaluation of the solution of a problem solving task). The results suggest that: (1) There was a significant difference of overall TI score between the instructor and students before engaging in self-evaluation of the solution of a problem solving task: $t(103)=35.409, p<.001$; and (2) There was a significant difference of the instructor's and students' overall task interpretation scores after engaging in self-evaluation of the solution of a problem solving task: $t(111)=37.42, p<.001$.

Moreover, it was also found that students' overall TI score before engaging in self-evaluation of the problem solution was 0.998 (i.e., 50 percent) and after engaging in self-evaluation of the problem solution students' overall TI score increased to 1.110 (i.e., 56 percent). Although there were significant differences between instructor and students' overall task interpretation scores, the analysis showed that students' self-evaluation of the problem solution activity did improve by $6 \%$ student's understanding of the problem.

The second and third sets of paired t-tests evaluated the mean differences between instructor's and students' explicit and implicit task interpretation scores before and after engaging in self-evaluation of the problem solution. The findings suggest that: (1) there was a significant difference between instructor's and students' explicit task interpretation scores before and after engaging in self-evaluation of the problem solution; and (2) there was a significant difference between instructor's and students' implicit task interpretation scores before and after engaging in self-evaluation of the problem solution, see Table 1. 
Table 1. Gaps between instructor's and students' task interpretation of all assigned problems

\begin{tabular}{|c|c|c|c|c|c|c|}
\hline & \multicolumn{3}{|c|}{ Before self-evaluation of the problem solution } & \multicolumn{3}{|c|}{ After self-evaluation of the problem solution } \\
\hline & TI Score & $t$ & $p$ & TI Score & $t$ & $p$ \\
\hline Overall Task Interpretation Score & $\begin{array}{c}\text { Instructor: } 2.000 \\
\text { Students: } .998\end{array}$ & 35.409 & $<.001$ & $\begin{array}{l}\text { Instructor: } 2.000 \\
\text { Students: } 1.110\end{array}$ & 37.416 & $<.001$ \\
\hline Explicit Task Interpretation Score & $\begin{array}{l}\text { Instructor: } 2.000 \\
\text { Students: } 1.353\end{array}$ & 20.693 & $<.001$ & $\begin{array}{l}\text { Instructor: } 2.000 \\
\text { Students: } 1.356\end{array}$ & 19.990 & $<.001$ \\
\hline Implicit Task Interpretation Score & $\begin{array}{c}\text { Instructor: } 2.000 \\
\text { Students: } .820\end{array}$ & 44.396 & $<.001$ & $\begin{array}{c}\text { Instructor: } 2.000 \\
\text { Students: } .825\end{array}$ & 37.874 & $<.001$ \\
\hline
\end{tabular}

4.2 Addressing Research Question 2: How Do Students' Task Interpretation (Explicit And Implicit) Change after Engaging in Self-Evaluation of Their Problem-Solving Processes?

For the first problem (i.e., Task 1 - the least difficult problem), the findings suggest that there was a significant improvement of students' overall task interpretation score after engaging in self-evaluation of the solution of a problem-solving task, $t(85)=2.50, p<.05$. However, when evaluating the explicit feature of the students' task interpretation, the findings showed no significant improvement of students' explicit task interpretation score, $t(85)$ $=1.19, p>.05$. A significant improvement was found on the implicit feature of students' task interpretation, $t(85)=$ $2.75, p<.01$, see Table 2 . This suggests that although students' explicit TI score was slightly higher after engaging in self-evaluation of the problem solution, it seemed like student self-evaluation of the problem solution did improve significantly their implicit task interpretation score.

Table 2. Task interpretation scores change (Task \#1-Least difficult problem)

\begin{tabular}{ccccc}
\hline & $\begin{array}{c}\text { Before self-evaluation of the } \\
\text { problem solution }\end{array}$ & $\begin{array}{c}\text { After self-evaluation of the } \\
\text { problem solution }\end{array}$ & $t$ & $p$ \\
\hline \multirow{2}{*}{ Overall Task Interpretation Score } & .996 & 1.063 & 2.50 & $<.05$ \\
& $(50 \%)$ & $(53 \%)$ & & \\
Explicit Task Interpretation Score & 1.257 & 1.301 & & \\
& $(63 \%)$ & $(65 \%)$ & & \\
Implicit Task Interpretation Score & .734 & .825 & 2.05 & $<.01$ \\
\hline
\end{tabular}

For the moderately difficult problem (i.e., Task 2), no significant change of students' overall task interpretation score was found, $t(97)=.706, p>.05$. Similarly, no significant change was also found for the explicit and implicit features of students' task interpretation scores, $t(97)=.618, p>.05$ and $t(97)=.316, p>.05$, respectively, see Table 3.

Table 3. Task interpretation scores change (Task \#2-Moderately difficult problem)

\begin{tabular}{|c|c|c|c|c|}
\hline & $\begin{array}{c}\begin{array}{c}\text { Before self-evaluation of the problem } \\
\text { solution }\end{array} \\
\end{array}$ & $\begin{array}{c}\text { After self-evaluation of the problem } \\
\text { solution }\end{array}$ & $t$ & $p$ \\
\hline $\begin{array}{c}\text { Overall Task Interpretation } \\
\text { Score }\end{array}$ & $\begin{array}{l}1.138 \\
(57 \%)\end{array}$ & $\begin{array}{l}1.123 \\
(56 \%)\end{array}$ & .706 & $>.05$ \\
\hline $\begin{array}{c}\text { Explicit Task Interpretation } \\
\text { Score }\end{array}$ & $\begin{array}{l}1.304 \\
(65 \%)\end{array}$ & $\begin{array}{l}1.284 \\
(64 \%)\end{array}$ & .618 & $>.05$ \\
\hline $\begin{array}{c}\text { Implicit Task Interpretation } \\
\text { Score }\end{array}$ & $\begin{array}{c}.972 \\
(49 \%)\end{array}$ & $\begin{array}{c}.963 \\
(48 \%)\end{array}$ & .316 & $>.05$ \\
\hline
\end{tabular}

Similarly, when solving the most difficult problem (i.e., Task 3), no significant change was found on students' overall, explicit, and implicit task interpretation scores, $t(98)=.727, p>.05, t(98)=.092, p>.05$, and $t(98)=.903$, $p>.05$, respectively, see Table 4. These findings did show an indication of continuous improvement on students' 
TI scores (i.e., overall, explicit, and implicit) over the three assigned problem solving tasks.

Table 4. Task interpretation scores change (Task \#3-Most difficult problem)

\begin{tabular}{|c|c|c|c|c|}
\hline & $\begin{array}{c}\text { Before self-evaluation of the problem } \\
\text { solution }\end{array}$ & $\begin{array}{l}\text { After self-evaluation of the problem } \\
\text { solution }\end{array}$ & $t$ & $p$ \\
\hline $\begin{array}{l}\text { Overall Task Interpretation } \\
\text { Score }\end{array}$ & $\begin{array}{l}1.158 \\
(58 \%)\end{array}$ & $\begin{array}{l}1.142 \\
(57 \%)\end{array}$ & .727 & $>.05$ \\
\hline $\begin{array}{l}\text { Explicit Task Interpretation } \\
\text { Score }\end{array}$ & $\begin{array}{l}1.531 \\
(77 \%)\end{array}$ & $\begin{array}{l}1.528 \\
(76 \%)\end{array}$ & .092 & $>.05$ \\
\hline $\begin{array}{l}\text { Implicit Task Interpretation } \\
\text { Score }\end{array}$ & $\begin{array}{c}.786 \\
(39 \%) \\
\end{array}$ & $\begin{array}{c}.756 \\
(38 \%) \\
\end{array}$ & .903 & $>.05$ \\
\hline
\end{tabular}

However, when comparing students' TI explicit and implicit scores before and after students' self-evaluation of the problem solution, across these three problems, the findings suggest that students' TI implicit scores were significantly lower than their paired TI explicit scores, see Tables 5 and 6 . These lower TI implicit scores compared to its explicit scores were consistent with the previous findings.

Table 5. Students' explicit and implicit task interpretation scores before self-evaluation of the solution across 3 problems

\begin{tabular}{ccccc}
\hline & $\begin{array}{c}\text { Explicit TI } \\
\text { Score }\end{array}$ & $\begin{array}{c}\text { Implicit TI } \\
\text { Score }\end{array}$ & $t$ & $p$ \\
\hline Least Difficult Problem & 1.257 & .734 & \multirow{2}{*}{11.803} & $<.001$ \\
(Task 1) & $(63 \%)$ & $(37 \%)$ & & \\
Moderately Difficult Problem & 1.304 & .972 & 7.753 & $<.001$ \\
(Task 2) & $(65 \%)$ & $(49 \%)$ & & \\
Most Difficult Problem & 1.531 & .786 & 20.940 & $<.001$ \\
(Task 3) & $(77 \%)$ & $(39 \%)$ & & \\
\hline
\end{tabular}

Table 6. Students' explicit and implicit task interpretation scores after self-evaluation of the solution across 3 problems

\begin{tabular}{ccccc}
\hline & $\begin{array}{c}\text { Explicit TI } \\
\text { Score }\end{array}$ & $\begin{array}{c}\text { Implicit TI } \\
\text { Score }\end{array}$ & $t$ & $p$ \\
\hline Least Difficult Problem & 1.301 & .825 & \multirow{2}{*}{12.509} & $<.001$ \\
(Task 1) & $(65 \%)$ & $(41 \%)$ & & \\
Moderately Difficult Problem & 1.284 & 0.963 & \multirow{2}{*}{6.698} & $<.001$ \\
(Task 2) & $(64 \%)$ & $(48 \%)$ & & \\
Most Difficult Problem & 1.528 & .756 & \multirow{2}{*}{19.426} & $<.001$ \\
(Task 3) & $(76 \%)$ & $(38 \%)$ & & \\
\hline
\end{tabular}

\section{Conclusions and Discussion}

It was not a surprise to see that there was a gap between what relevant information (explicit and implicit) of a problem is essential for the instructor and students. The analysis of the $t$-test revealed a significant difference between the instructor's and students' task interpretation scores of all assigned problems (as shown in Table 1). One possible explanation for this phenomenon is that experts' cumulative problem-solving experiences enable them to develop complex schema structure which sometimes make them oblivious to the complexity of their thinking process (Jones \& Idol, 2013).

Further analyses of the $t$-tests revealed a significant difference between the students' ability to identify the explicit and implicit information associated with the assigned task (see Tables 2-5). Students' scores indicate a higher ability to identify the explicit understanding of problem than the implicit one. This suggests that the students seem to experience more challenges to identify information beyond the problem description, such as the purpose for the problem assigned, connections to learning concepts, and potential resources for completing the task. While implicit information often seems obvious to the instructors, students may face difficulty in making the connections 
between information that is presented in problem description (and class discussion) and information that the students need to extrapolate beyond the problem description. Furthermore, problem complexity might influence students' ability to extrapolate relevant information from the problem (as seen on the lower Implicit TI score of Task 3). Van Meter et al. (2016) argue that students' conceptual understanding and reasoning can be improved through self-regulation practices (i.e., organizing, elaborating, and monitoring).

Despite higher explicit task interpretation scores, instructors may not expect their students to be able to grasp all of the explicit information given by the problem description or discussed during class. The findings show students' explicit task interpretation scores ranges from 1.257 to 1.531 (on a $0-2$ scale). It appears that students in this study were able to grasp 63 to 77 percent of information explicitly presented to them while engaged in problem-solving activities. This finding aligns with the novice-expert research findings that suggest experts spend more time on understanding the task and engaging in monitoring and evaluation, in the attempt to develop more complete representation of the problem, before finding the appropriate strategies to solve problems (Abelson, 1981; Glaser, 1992; Herbig \& Glöckner, 2009; Hoffman, 1996; Lesgold et al., 1988; Soloway, Adelson, \& Ehrlich, 1988).

Although it is inconclusive, students' self-evaluation of the problem solution may help improve their task interpretation skills (see Tables 2-4); however, this study shows significant improvement only on students' implicit task interpretation skills while solving the least difficult problem. Self-evaluation of the problem solution did not seem to significantly improve students' task interpretation scores when it comes to solving problems that are more difficult. These non-significant TI changes may be caused by students' ability to learn the TI strategy from self-evaluation of the problem solution on the first problem (i.e., the least difficult problem), or students may have difficulty identifying essential implicit information necessary (e.g., relevant concepts) to solve problems that are more complex. From an instructional perspective, it is also possible that students did not fully utilize self-evaluation due to lack of more specific instruction. Numerous studies argue that a strong instructional guidance is more suitable for novice and intermediate learners (Ackermann, 1996; Kirschner, Sweller, \& Clark, 2006; Reder, Anderson, \& Simon, 1996). Further investigation is needed to better understand how students' self-evaluation of the problem solutions can be used to improve both explicit and implicit task interpretation, as well as other SRL features, for problems of varying complexities.

\section{Acknowledgments}

This material is based, in part, upon work supported by the National Science Foundation under Grant No. 1148806. Any opinions, findings, and conclusions or recommendations expressed in this material are those of the author(s) and do not necessarily reflect the views of the National Science Foundation.

\section{References}

Abdillah, A., Nusantara, T., Subanj, S., Susanto, H., \& Abadyo, A. (2016). The Students Decision Making in Solving Discount Problem. International Education Studies, 9(7), 57. https://doi.org/10.5539/ies.v9n7p57

Abelson, R. P. (1981). Psychological status of the script concept. American Psychologist, 36, 715-729. https://doi.org/10.1037/0003-066X.36.7.715

Ackermann, E. K. (1996). Perspective-Taking and Object Construction: Two Keys to Learning. Constructionism in Practice: Designing, Thinking, and Learning in a Digital World, 25-37.

Andrade, H., \& Valtcheva, A. (2009). Promoting Learning and Achievement Through Self-Assessment. Theory Into Practice, 48(1), 12-19. https://doi.org/10.1080/00405840802577544

Boekaerts, M. (1997). Self-regulated learning: A new concept embraced by researchers, policy makers, educators, teachers, and students. Learning and Instruction, $7(2)$, 161-186. https://doi.org/10.1016/S0959-4752(96)00015-1

Brydges, R., \& Butler, D. (2012). A reflective analysis of medical education research on self-regulation in learning and practice. Medical Education, 46(1), 71-9. https://doi.org/10.1111/j.1365-2923.2011.04100.x

Butler, D. L. (1998). Metacognition and Learning Disabilities. In B. Y. L. Wong (Ed.), Learning About Learning Disabilities (2nd ed., pp. 277-307). Toronto: Academic Press.

Butler, D. L., \& Cartier, S. C. (2004). Learning in varying activities: An explanatory framework and a new evaluation tool founded on a model of self-regulated learning. In Annual Conference of the Canadian Society for The Study of Education. Toronto, ON. Retrieved from http://perso.crifpe.ca/ scartier/spip/IMG/pdf/Butler_and_Cartier_2004_.pdf

Butler, D. L., \& Cartier, S. C. (2005). Multiple Complementary Methods for Understanding Self-Regulated Learning as Situated in Context. In American Educational Research Association, Annual Meeting (pp. 
11-15).

Butler, D. L., Schnellert, L., \& MacNeil, K. (2015). Collaborative inquiry and distributed agency in educational change: A case study of a multi-level community of inquiry. Journal of Educational Change, 16(1), 1-26. https://doi.org/10.1007/s10833-014-9227-z

Butler, D. L., \& Winne, P. H. (1995). Feedback and Self-Regulated Learning: A Theoretical Synthesis. Review of Educational Research, 65(3), 245-281. https://doi.org/10.3102/00346543065003245

Carr, M., \& Biddlecomb, B. D. (1998). Metacognition in Educational Theory and Practice. In J. D. D. J. Hacker \& A. C. Graesser (Eds.), Metacognition in Educational Theory and Practice (pp. 69-92). Hillsdale, NJ, USA: $\quad$ Erlbaum: Retrieved from https://books.google.com/books?hl=en\&lr=\&id=EzWRAgAAQBAJ\&oi=fnd\&pg=PA69\&dq=Metacognitio $\mathrm{n}+\mathrm{in}+$ mathematics + from $+\mathrm{a}+$ constructivist + perspective

Cartier, S. C., \& Butler, D. L. (2004). Elaboration and validation of questionnaires and plan for analysis. In Annual Conference of the Canadian Society for The Study of Education. Toronto, ON.

Case, J., Gunstone, R., \& Lewis, A. (2001). Students' Metacognitive Development in an Innovative Second Year Chemical Engineering Course. Research in Science Education, 31(3), 313-335. https://doi.org/10.1023/A:1013113807788

Coutinho, S. A. (2007). The relationship between goals, metacognition, and academic success. Educate, 7(1), 39-47. Retrieved from http://www.educatejournal.org/index.php/educate/issue/view/23

Coutinho, S. A. (2008). Self-Efficacy, Metacognition, and Performance. North American Journal of Psychology, 10(1), 165-172. $\quad$ Retrieved from http://xz6kg9rb2j.search.serialssolutions.com/?ctx_ver=Z39.88-2004\&ctx_enc=info:ofi/enc:UTF-8\&rfr_id= info:sid/ProQ\%3A\&rft_val_fmt=info:ofi/fmt:kev:mtx:journal\&rft.genre=article\&rft.jtitle=North+American + Journal+of+Psychology\&rft.atitle=Self-Efficacy $\% 2 \mathrm{C}+\mathrm{Me}$

De Corte, E., Mason, L., Depaepe, F., \& Verschaffel, L. (2011). Handbook of Self-Regulation of Learning and Performance. In B. J. Zimmerman, \& D. H. Schunk (Eds.), Handbook of Self-Regulation of Learning and Performance (pp. 155-172). New York, New York, USA: Routledge. Retrieved from https://books.google.com/books?hl=en\&lr=\&id=XfOYV0lwzGgC\&oi=fnd\&pg=PA155\&dq=Self-regulatio $\mathrm{n}+$ of + mathematical+knowledge+and+skills\&ots=4KylGsjQ5D\&sig=ySNDNL-m0IyCYTeMWplBo63Ku6 $\mathrm{s} \# \mathrm{v}=$ onepage \&q$=$ Self-regulation of mathematical knowledge and skills $\& \mathrm{f}=\mathrm{fa}$

Dinsmore, D. L., Alexander, P. A., \& Loughlin, S. M. (2008). Focusing the conceptual lens on metacognition, self-regulation, and self-regulated learning. Educational Psychology Review, 20(4), 391-409. https://doi.org/10.1007/s10648-008-9083-6

Downing, K., Kwong, T., Chan, S.-W., Lam, T.-F., \& Downing, W.-K. (2009). Problem-based learning and the development of metacognition. Higher Education, 57(5), https://doi.org/10.1007/s10734-008-9165-x

Engineering Accreditation Commission. (2003). Criteria for accrediting engineering program. ABET Report E1 11/19. Baltimore, Md. Retrieved from http://www.abet.org/criteria_eac.html

Ferla, J., Valcke, M., \& Schuyten, G. (2009). Student models of learning and their impact on study strategies. Studies in Higher Education, 34(2), 185-202. https://doi.org/10.1080/03075070802528288

Georghiades, P. (2000). Beyond conceptual change learning in science education: focusing on transfer, durability and metacognition. Educational Research, 42(2), 119-139. https://doi.org/10.1080/001318800363773

Glaser, R. (1992). Expert knowledge and processes of thinking. In D. Halpern (Ed.), Enhancing thinking skills in the sciences and mathematics (pp. 63-75). Hillsdale, NJ, USA: Lawrence Erlbaum Associates, Inc.

Hadwin, A., Oshige, M., Miller, M., \& Wild, P. (2009). Examining Student and Instructor Task Perceptions in a Complex Engineering Design Task. In The Sixth International Conference on Innovation and Practices in Engineering Design and Engineering Education. Hamilton, ON, Canada: McMaster University.

Herbig, B., \& Glöckner, A. (2009). Experts and Decision Making: First Steps towards a Unifying Theory of Decision Making in Novices, Intermediates and Experts. MPI Collective Goods Preprint, 2009(2). https://doi.org/10.2139/ssrn.1337449

Hoffman, R. R. (1996). How can expertise be defined? Implications of research from cognitive psychology. In R. Williams, W. Faulkner, \& J. Fleck (Eds.), Exploring Expertise (pp. 81-100). Edinburgh, Scotland: 
University of Edinburgh Press.

Jonassen, D. H. (2004). Learning to Solve Problems: An Instructional Design Guide. (M. Davis, Ed.). John Wiley \& Sons. Retrieved from http://books.google.com/books?hl=en\&amp;lr=\&amp;id=g0ffeIYunUwC\&amp;oi=fnd\&amp;pg=PR19\&am $\mathrm{p} ; \mathrm{dq}=$ Learning + to + Solve+Problems +-+ An+Instructional+Design+Guide.\&amp;ots=CwtuzC-eif\&amp;sig= 8RViEweiisMtRS2X15t7Lup4HYY

Jones, B. F., \& Idol, L. (2013). Dimensions of Thinking and Cognitive Instruction. Routledge. Retrieved from https://books.google.com/books?hl=en\&lr=\&id=cMvwdraULp0C\&pgis=1

Kahneman, D. (2003). A Perspective on Judgment and Choice: Mapping Bounded Rationality. American Psychologist, 58(9), 697-720. https://doi.org/10.1037/0003-066X.58.9.697

Kearsley, P. D., \& Klein, A. G. (2016). Self-corrected homework for incentivizing metacognition. In American Society for Engineering Education Annual Conference. New Orleans, LA, USA. https://doi.org/10.18260/p.26155

Kim, E., \& Kim, K. (2015). Cognitive styles in design problem solving: Insights from network-based cognitive maps. Design Studies, 40, 1-38. https://doi.org/10.1016/j.destud.2015.05.002

Kirschner, P. A., Sweller, J., \& Clark, R. E. (2006). Why Minimal Guidance During Instruction Does Not Work: An Analysis of the Failure of Constructivist, Discovery, Problem-Based, Experiential, and Inquiry-Based Teaching. Educational Psychologist, 41(2), 75-86. https://doi.org/10.1207/s15326985ep4102_1

Koichu, B., \& Leron, U. (2015). Proving as problem solving: The role of cognitive decoupling. The Journal of Mathematical Behavior, 40, 233-244. https://doi.org/10.1016/j.jmathb.2015.10.005

Lawanto, O., Butler, D., Cartier, S., Santoso, H. B., \& Goodridge, W. (2013). Task Interpretation, Cognitive, and Metacognitive Strategies of Higher and Lower Performers in an Engineering Design Project: An Exploratory Study of College Freshmen. International Journal of Engineering Education, 29(2), 459-475.

Lawanto, O., Butler, D., Cartier, S., Santoso, H., Lawanto, K., \& Clark, D. (2013). An Exploratory Study of Self-Regulated Learning Strategies in a Design Project by Students in Grades 9-12. Design and Technology Education, 18(1), 44-57. Retrieved from https://eric.ed.gov/?id=EJ1007162

Lesgold, A. M., Rubinson, H., Feltovich, P., Glaser, R., Klopfer, D., \& Wang, Y. (1988). Expertise in a complex skill: Diagnosing X-ray pictures. In M. T. H. Chi, R. Glaser, \& M. T. Farr (Eds.), The Nature of Expertise (pp. 311-342). Hillsdale, NJ, USA: Erlbaum.

Lubis, A., \& Nasution, A. A. (2017). How Do Higher-Education Students Use Their Initial Understanding to Deal with Contextual Logic-Based Problems in Discrete Mathematics? International Education Studies, 10(5), 72. https://doi.org/10.5539/ies.v10n5p72

Mairing, J. P. (2016). Thinking Process of Naive Problem Solvers to Solve Mathematical Problems. International Education Studies, 10(1), 1. https://doi.org/10.5539/ies.v10n1p1

Marchis, I. (2011). How Mathematics Teachers Develop Their Pupils' Self-Regulated Learning Skills. Acta Didactica Napocensia, 4, 9-14. Retrieved from https://eric.ed.gov/?id=EJ1055885

Moore, T. J., Miller, R. L., Lesh, R. A., Stohlmann, M. S., \& Kim, Y. R. (2013). Modeling in Engineering: The Role of Representational Fluency in Students' Conceptual Understanding. Journal of Engineering Education, 102(1), 141-178. https://doi.org/10.1002/jee.20004

National Research Council (Ed.). (2000). How People Learn: Brain, Mind, Experience, and School (Expanded). Washington, DC, USA: The National Academies Press.

Otero, J., Campanario, J. M., \& Hopkins, K. D. (1992). The Relationship between Academic Achievement and Metacognitive Comprehension Monitoring Ability of Spanish Secondary School Students. Educational and Psychological Measurement, 52(2), 419-430. https://doi.org/10.1177/0013164492052002017

Paris, S. G. (1986). Teaching children to guide their reading and learning. In T. Raphael (Ed.), The Context of School-Based Literacy (pp. 115-130). New York, New York, USA: Random House.

Paris, S. G., \& Winograd, P. (1990). Metacognition in academic learning and instruction. In B. F. Jones (Ed.), Dimension of Thinking and Cognitive Instruction (pp. 15-44). Erlbaum, NJ, USA: Ed. Hillsdale.

Phelps, R., Ellis, A., \& Hase, S. (2002). The role of metacognitive and reflective learning processes in developing capable computer users. In The 18th Annual Conference of the Australasian Society for 
Computers in Learning in Tertiary Education (ASCILITE) (pp. 481-490). Melbourne, Victoria, AU: University of Melbourne. Retrieved from https://epubs.scu.edu.au/cgi/viewcontent.cgi?article=1003\&context=educ_pubs

Phelps, R., Graham, A., \& Thornton, P. (2006). Technology together: Getting whole schools involved with ICT through a metacognitive approach. Australian Educational Leader, 28(1), 22-24. Retrieved from https://search.informit.com.au/documentSummary;dn=695833809081952;res=IELAPA

Pintrich, P. (2002). The role of metacognitive knowledge in learning, teaching, and assessing. Theory into Practice, 41(4), 231-236. https://doi.org/10.1207/s15430421tip4104_3

Polya, G. (1957). How to solve it (2nd ed.). Princeton, NJ: Princeton University Press.

Reder, L., Anderson, J. R., \& Simon, H. A. (1996). Situated Learning and Education. Educational Researcher, 25(4), 5-11. https://doi.org/10.3102/0013189X025004005

Rickey, D., \& Stacy, A. M. (2000). The Role of Metacognition in Learning Chemistry. Journal of Chemical Education, 77(7), 915. https://doi.org/10.1021/ed077p915

Rivera-Reyes, P. (2015). Students' Task Interpretation and Conceptual Understanding in Electronics Laboratory Work (Doctoral Dissertation). Logan, UT: Utah State University.

Rivera-Reyes, P., Lawanto, O., \& Pate, M. L. (2016). Understanding Student Coregulation in Task Interpretation during Electronics Laboratory Activities. International Education Studies, 9(7), 1. https://doi.org/10.5539/ies.v9n7p1

Rivera-Reyes, P., Lawanto, O., \& Pate, M. L. (2017). Students' Task Interpretation and Conceptual Understanding in an Electronics Laboratory. IEEE Transactions on Education, 60(4), 265-272. https://doi.org/10.1109/TE.2017.2689723

Samuelsson, J. (2008). The impact of different teaching methods on students' arithmetic and self-regulated learning skills. Educational Psychology in Practice, 24(3), 237-250. https://doi.org/10.1080/02667360802256790

Schraw, G., Crippen, K. J., \& Hartley, K. (2006). Promoting Self-Regulation in Science Education: Metacognition as Part of a Broader Perspective on Learning. Research in Science Education, 36(1-2), 111-139. https://doi.org/10.1007/s11165-005-3917-8

Soloway, E., Adelson, B., \& Ehrlich, K. (1988). Knowledge and process in the comprehension of computer programs. In M. T. H. Chi \& M. J. Farr (Eds.), The Nature of Expertise (pp. 129-152). Hillsdale, NJ, USA: Erlbaum.

Van Meter, P. N., Firetto, C. M., Turns, S. R., Litzinger, T. A., Cameron, C. E., \& Shaw, C. W. (2016). Improving Students' Conceptual Reasoning by Prompting Cognitive Operations. Journal of Engineering Education, 105(2), 245-277. https://doi.org/10.1002/jee.20120

Wolters, C. A. (1998). Self-regulated learning and college students' regulation of motivation. Journal of Educational Psychology, 90(2), 224-235. https://doi.org/10.1037/0022-0663.90.2.224

Zimmerman, B. J., Heart, N., \& Mellins, R. B. (1989). A Social Cognitive View of Self-Regulated Academic Learning. Journal of Educational Psychology, 81(3), 329-339. https://doi.org/10.1037//0022-0663.81.3.329

\section{Copyrights}

Copyright for this article is retained by the author(s), with first publication rights granted to the journal.

This is an open-access article distributed under the terms and conditions of the Creative Commons Attribution license (http://creativecommons.org/licenses/by/4.0/). 